\title{
Chemical and Nutrient Composition of Selected Banana Varieties of Kerala
}

\author{
Siji $S^{*}$, Nandini P.V
}

College of Agriculture, Vellayani, Thiruvananthapuram, India

\begin{abstract}
Banana is the common name for herbaceous plants of the genus Musa and for the fruit they produce. Many studies shows that banana is richest source of various nutrients which having the health beneficial for humans. The chemical and nutrient compositions of eight banana varieties were studied. TSS was found to be more in Kadali $\left(23.90^{\circ}\right.$ Brix) followed by Rasakadali $\left(23.83^{\circ}\right.$ Brix) and Nendran $\left(22^{\circ}\right.$ Brix). Maximum Acidity was noticed in Poovan (1.28\%). The variety Nendran exhibited highest carbohydrate content $(41.33 \mathrm{~g} / 100 \mathrm{~g})$ where as protein content was found to be higher in variety Poovan (1.37g/100g). Total mineral content of banana varieties ranged between $0.17 \mathrm{~g}$ - $0.70 \mathrm{~g} / 100 \mathrm{~g}$ and varieties such as Rasakadali (260 mg/lo0g) and Nendran ( $546.66 \mathrm{mg} / 100 \mathrm{~g}$ ) exhibited highest content of $\mathrm{Na}$ and $\mathrm{K}$ respectively. The calcium content of the selected banana varieties ranged between $0.35-1.35 \mathrm{mg} / 100 \mathrm{~g}$.
\end{abstract}

Keywords - TSS, Acidity, Total carbohydrate, Protein, Total minerals, Sodium, Potassium, Calcium.

\section{INTRODUCTION}

The word "banana" is a general term comprising a number of species or hybrids in the genus Musa of family Musaceae. Bananas are cultivated commercially under tropical and subtropical conditions in all the states of India, except in those having extreme winter such as Himachal Pradesh, Jammu and Kashmir. Tamil Nadu is the top banana producing state. In India more than 600 varieties are known, but often many of the varieties carry a lot of synonyms.

India ranks first in production and third in area among fruit crops (DAC, 2014). Total production of banana in Kerala was 472.93 tons (NHB, 2014).

Nationally, Kerala occupies 50 per cent of the total area of banana and maximum quantity of the fruit is sold locally. Banana reaches their greatest importance as a staple food crops in the parts of East Asian where annual consumption is over $200 \mathrm{~kg}$ / capital year (Valmayor, 1994).
The banana is of great nutritional value. It is a good source of calories, vitamins and minerals. People of South India, traditionally use banana as a wholesome food.

Banana is nutritious and easily digestible than any other fruits. Bananas are popular for their aroma and texture besides rich in potassium and calcium and low in sodium content (Sharrock and Lustry, 2000). Hence, the present study is an evaluation of chemical and nutrient composition present in selected banana varieties mostly consumed in Kerala.

\section{MATERIALS AND METHODS}

Eight ripe banana varieties used for table purpose were selected for the study. The varieties selected were Palayankodan (AAB), Rasakadali (AB), Robusta (AAA), Poovan (AAB), Nendran (AAB), Kadali (AA), Red banana (AAA), Padatti (AAB). The banana varieties were procured at the time when the characteristic fruit colour developed for each type. They were collected from Instructional Farm, College of Agriculture, Vellayani and local markets of Trivandrum. Total soluble solids (TSS), acidity, total carbohydrate, protein, total minerals, sodium, potassium, and calcium were selected for determining chemical and nutrient composition of selected banana varieties.

Estimation of total soluble solids

The total soluble solids in the bananas were estimated by means of refractometer as ${ }^{0}$ Brix in $0.1 \%$ graduations (AOAC, 2000).

Estimation of acidity and Total carbohydrate

The acidity and carbohydrate content of banana samples were estimated by the method described by Sadasivam and Manickam (2008).

\section{Estimation of protein}

The nitrogen content of banana samples was estimated by micro Kjeldahl's wet digestion method. The values of nitrogen contents were multiplied by the factors 6.25 to get crude protein content (AOAC, 2000).

Estimation of total minerals

Total mineral content was estimated as per the method described by Raghuramalu et al. (1983). 


\section{Estimation of sodium and Potassium}

Sodium and potassium were estimated by the method suggested by Jackson (1973) using flame photometer.

\section{Estimation of calcium}

Calcium was estimated by EDTA method suggested by Sadasivam and Manickam (2008)

\section{STATISTICAL ANALYSIS}

All the analyses were done in triplicates. In order to obtain suitable interpretation the generated data was subjected to statistical analysis such as One-way Analysis of Variance (ANOVA) at $0.05 \%$.

\section{RESULTS AND DISCUSSION}

TSS can serve as a useful index in the determination of fruit maturity and ripeness. According to $\mathrm{Lu}$ (2004), total soluble solid (TSS) is an important quality attribute for many fresh fruits during ripening.

In the present study, highest TSS content was observed for variety Kadali $\left(23.90^{\circ}\right.$ Brix $)$ and the lowest for variety Padatti $\left(17.83^{0}\right.$ Brix) (Table 1). The study is in agreement with the findings of Sandipkumar and Shanmugasundaram (2015) who had found that TSS content was increased up to $22.24^{0}$ Brix during the period of storage in Monthan banana, and the magnitude of increase of total soluble solids in banana is dependent on cultivar.

Table.1: TSS, acidity and total carbohydrate content of banana varieties

\begin{tabular}{|c|l|c|c|c|}
\hline Sl.No & \multicolumn{1}{|c|}{ Name } & $\begin{array}{c}\text { TSS } \\
\left({ }^{\mathbf{0}} \text { Brix }\right)\end{array}$ & Acidity (\%) & $\begin{array}{c}\text { Carbohydrate } \\
(\mathbf{g} / \mathbf{1 0 0} \text { g) }\end{array}$ \\
\hline 1 & Palayankodan (AAB) & 18.53 & 0.72 & 31.10 \\
\hline 2 & Rasakadali (AB) & 23.83 & 0.71 & 30.73 \\
\hline 3 & Robusta (AAA) & 20.30 & 0.47 & 22.63 \\
\hline 4 & Poovan (AAB) & 20.10 & 1.28 & 38.77 \\
\hline 5 & Nendran (AAB) & 22.00 & 0.84 & 41.33 \\
\hline 6 & Kadali (AA) & 23.90 & 0.46 & 32.13 \\
\hline 7 & Red banana (AAA) & 21.60 & 0.48 & 21.70 \\
\hline 8 & Padatti (AAB) & 17.83 & 0.94 & 26.66 \\
\hline CD(0.05) & & $\mathbf{0 . 6 5 9}$ & $\mathbf{0 . 1 2 5}$ & $\mathbf{1 . 4 3 9}$ \\
\hline
\end{tabular}

In the present study, varietal difference in terms of titrable acidity was observed to be statistically highly significant. The variety Kadali was found to be less acidic $(0.46 \%)$ when compared to other varieties (Table 1). According to Sadler and Murphy (2010), titrable acidity is measured for the determination of total acid content present in a food. In fruits, acidity decreases with ripening of fruits. Sreedevi and Suma (2015) in their study on "A comparative quality analysis of banana (Var. Palayankodan)" reported that acidity content of inorganically cultivated Palayankodan was higher when compared to organically cultivated Palayankodan.
The present study revealed that highest carbohydrate content was noticed in variety Nendran $(41.33 \mathrm{~g} / 100 \mathrm{~g})$ and lowest $(21.70 \mathrm{~g} / 100 \mathrm{~g})$ in variety Red banana (Table 1$)$. The study is in accordance with the findings of Anyasi et al. (2013) who had reported a CHO content of $22 \mathrm{~g} / 100 \mathrm{~g}$ in Cavendish banana.

A study conducted by Tamil and Mukunthan (2012) had reported that variety Moris $(13.4 \mathrm{mg})$ contained high amount of total carbohydrate followed by variety Rasthali (12.9mg), Hill banana (12.3mg), Nendran (11 mg) and Red banana $(9.4 \mathrm{mg})$.

Table.2: Protein, total mineral and calcium content of banana varieties

\begin{tabular}{|c|l|c|c|c|}
\hline Sl.No & \multicolumn{1}{|c|}{ Name } & $\begin{array}{c}\text { Protein } \\
(\mathbf{g} / \mathbf{1 0 0 g})\end{array}$ & $\begin{array}{c}\text { Total minerals } \\
(\mathbf{g} / \mathbf{1 0 0 g})\end{array}$ & $\begin{array}{l}\text { Calcium } \\
(\mathbf{m g} / \mathbf{1 0 0 g})\end{array}$ \\
\hline 1 & Palayankodan (AAB) & 1.14 & 0.182 & 1.35 \\
\hline 2 & Rasakadali (AB) & 0.91 & 0.58 & 0.79 \\
\hline 3 & Robusta (AAA) & 1.33 & 0.17 & 0.85 \\
\hline
\end{tabular}




\begin{tabular}{|c|l|c|c|c|}
\hline 4 & Poovan (AAB) & 1.37 & 0.48 & 0.80 \\
\hline 5 & Nendran (AAB) & 1.11 & 0.68 & 0.62 \\
\hline 6 & Kadali (AA) & 1.37 & 0.33 & 0.48 \\
\hline 7 & Red banana ( AAA) & 1.34 & 0.70 & 0.35 \\
\hline 8 & Padatti (AAB) & 1.28 & 0.30 & 0.85 \\
\hline CD(0.05) & $\mathbf{0 . 2 1 3}$ & $\mathbf{0 . 1 2 1}$ & $\mathbf{0 . 1 8 7}$ \\
\hline
\end{tabular}

In the present study, highest protein content was observed in variety Poovan $(1.37 \mathrm{~g} / 100 \mathrm{~g})$ and was significantly different from other types. Variety Rasakadali $(0.9 \mathrm{~g} / 100 \mathrm{~g})$ showed lowest protein content (Table 2). The results are in accordance with the findings of Aurore et al. (2009) who had also reported protein content of 1.1 per cent in Musa AAA Cavendish.

Minerals play an important role in maintaining proper function and good health in the human body. Inadequate intake of minerals in the diet weakens the immune system in human body and hence increases the susceptibility to infectious diseases. The source of essential elements in human body is through diet (Chaturvedi et al., 2004). The highest total mineral content was found in variety Red banana $(0.70 \mathrm{~g} / 100 \mathrm{~g})$.

The findings of present study revealed that calcium content of variety Palayankodan was found to be highest $(1.35 \mathrm{mg} / 100 \mathrm{~g})$. The lowest calcium content $(0.35 \mathrm{mg} / 100 \mathrm{~g})$ was observed in variety Red banana (Table 2). Smitha et al. (2015) opined that calcium content of banana varieties in Karnataka, ranged from 17.15 to $47.19 \mathrm{mg}$ per $100 \mathrm{~g}$ fresh weight.

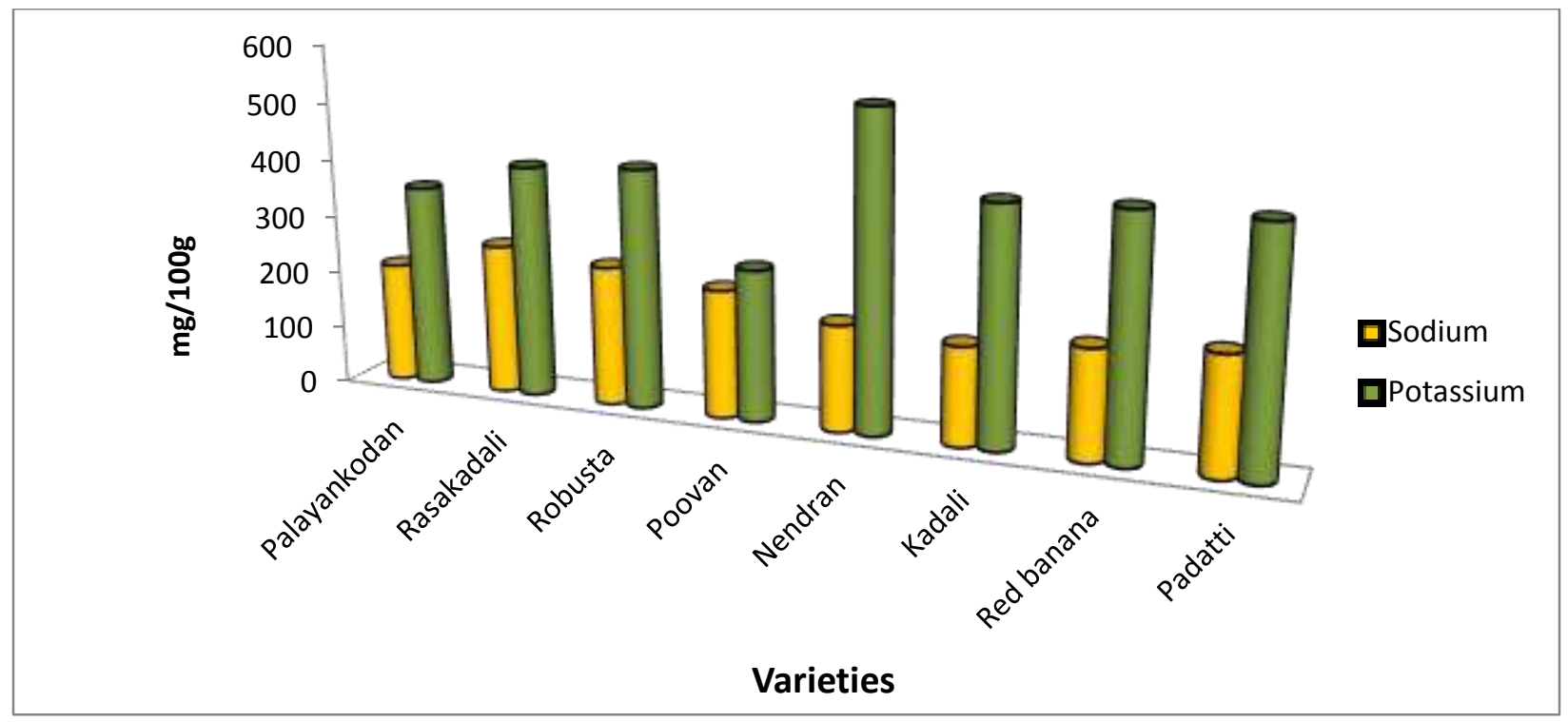

Fig.1: Sodium and Potassium content of banana varieties

The study revealed a significant difference among the varieties with respect to sodium content. Variety Rasakadali $(260 \mathrm{mg} / 100 \mathrm{~g})$ exhibited highest sodium content followed by variety Robusta $(241.66 \mathrm{mg} / 100 \mathrm{~g})$. Sodium content was found to be minimum for variety Kadali $(170.00 \mathrm{mg} / 100 \mathrm{~g})$ (Fig 1). Sodium being the most abundant mineral found in the fruits. Low sodium diet has been reported to be beneficial in the prevention of high blood pressure.

Among fruits, banana is valued for potassium content, because of its role in maintaining the body's blood pressure. The present study revealed that potassium content was found to be highest in variety Nendran $(546.66 \mathrm{mg} / 100 \mathrm{~g})$ and lowest in variety Poovan $(261.66 \mathrm{mg} / 100 \mathrm{~g})$. The results are in close agreement with the findings of Jyothirmayi and Rao (2015) and Sampath et al (2012) who had also reported potassium content of $358 \mathrm{mg}$ and $467 \mathrm{mg}$ respectively $/ 100 \mathrm{~g}$ of banana studied.

\section{CONCLUSION}

The banana is of great nutritional value. It is a good source of calories, vitamins and minerals. People of South India, traditionally use banana as a wholesome food. Chemical and nutrient composition of banana varieties varied according to the variety, cultivation practices, weather, type 
of soil, degree of maturity and the condition of ripeness. The present study indicated that banana is a highly nutritious fruit. It is an excellent source of potassium and carbohydrate and a good food for all ages of people. In vitro studies and animal model studies and clinical studies show that banana act as a food medicine for treatment of various disease like hypertension, ulcers, diarrhoea, Alzheimer's disease due to its chemical and nutrient contents.

\section{REFERENCES}

[1] Anyasi T,A., Jideani, A..IO.and Mchau, G.R.A. 2013. Functional properties and postharvest utilization of commercial and non commercial banana cultivars. Compr.Rev Food Sci. Food Saf. 12 (5): 509-521.

[2] AOAC, 2000.Official Methods of Analysis. 17 $7^{\text {th }}$ Edn, Association of Analytical Chemists. Washington D.C.1212p.

[3] Aurore, G., Parfait, B. and Fahrasmane, L. 2009. Bananas, raw materials for making processed food products. Trends Food Sci Technol. 20: 78-91.

[4] Chaturvedi, U. C., Shrivastava, R. and Upreti, R. K. 2004.Current Science. 87(11): 1536.

[5] DAC (Department of Agriculture and Cooperation).2014. Hand book on Horticulture Statistics. Government of India. New Delhi. 12p.

[6] Jackson, M.L., 1973. Soil chemical analysis. Prentice Hall of India Private Ltd, New Delhi. 521p.

[7] Jyothirmayi, N. and Rao, N. M. 2015. Banana. Medicinal uses. J. Med. Sci Technol. 4(2):152-160.

[8] Lu, R. 2004. Multispectral imaging for predicting firmness and soluble solid contents of apple fruit. Posthar Biol. Technol. 31 (3): 147-157.

[9] NHB [National Horticulture Board].2014. Annual Report. Ministry of Agriculture, Government of India. 8-9.

[10] Raghuramalu, N., Nair, M. K. and Kalyansundaram, S. 1983. Mannual of Laboratory Techniques, National Institute of Nutrition, ICMR, Hyderabad, India.

[11] Sadasivam, S. and Manickam, A. 2008. Biochemical Methods. $3^{\text {nd }}$ edn. New Age International Publications, New Delhi, India. 19-22pp.

[12] Sadler, G. D. and Murphy, P.A. 2010. pH and titrable acidity. Food Analysis. Springer Science Business Media, New York.pp.219-260.

[13] Sampath, K., Debjit, B., Duraivel, S. and Umadevi, M. 2012. Traditional and medicinal uses of banana. $J$. Pharmacognosy. Phytochem. 1(3): 51-63.
[14] Sandipkumar, K. P. and Shanmugasundaram. 2015. Physicochemical changes during ripening of Monthan banana. Int. J. Tech Enhan.EmergEngg. Res. 3(2): 1821.

[15] Sharrock, S. Lustry, C. 2000. Nutritive value of banana, in INIBAP. Annual Report Montpellier, France. 28-31 pp.

[16] Sreedevi, L. and Suma, D. 2015. A comparative quality analysis of banana (varPalayankodan). Int. Res. J. Bio Sci. 4(4):6-1.

[17] Tamil, S. Mukunthan, A. 2012. Different varieties of plantain (banana) and their estimation by chemical tests. Int. J. Comp. Org. Trends. 2(2): 1-9.

[18] Valmayor, R. V. 1994. Nematodes and weevil borer conference rational. Banana nematodes and weevil bores in Asia and Pacific.(eds. Valmayor, R. V. Siloyoi, B) INIBAP-ASPNET, Los Bonas, Philippines, 298-302pp. 